\title{
MARKETING STRATEGY IN INCREASING BALLROOM SALES AT NEW KUTA HOTEL
}

\author{
Monika Aprilia Wulandari ${ }^{1}$, Elvira Septevany ${ }^{2}$, I Gusti Agung Mas Krisna Komala \\ Sari $^{3}$, I Ketut Suarta ${ }^{4}$ \\ Politeknik Negeri Bali, Indonesia \\ monikaawulandari@gmail.com¹,elvira_s@pnb.ac.id², gungmaskrisna88@gmail.com³, \\ ketutsuarta@pnb.ac.id ${ }^{4}$
}

\begin{abstract}
This research aims to increase ballroom sales at New Kuta Hotel, to find out marketing strategies that should be used by the sales \& marketing departments to increase ballroom sales and to find out which strategies are most effective in marketing strategies by sales \& marketing department. The analysis techniques used are qualitative descriptive analysis, quantitative descriptive analysis, Internal Factor Analysis Summary Matrix (IFAS), External Factor Analysis Summary Matrix (EFAS), Internal-External Matrix (IE), SWOT Analysis and Quantitative Strategic Planning Matrix (QSPM). Based on the results of IFAS matrix analysis, the main strength is the ballroom sales can help increase hotel revenue, while the main weakness is the incentives imposed by the sales \& marketing departments are less appropriate. Based on the EFAS matrix analysis, it was discovered that the main opportunity was the ability of sales \& marketing to bring in customers while the main threat faced was the budget considered by the customer. The IE Matrix study results put the company in the Growth Strategic (Cell II) position. SWOT analysis produced eight alternative strategies of marketing strategies from the eight strategies and obtained three marketing strategies that were prioritized and calculated through QSPM Matrix with a total TAS of 181.29.
\end{abstract}

Keywords: Marketing Strategy; Marketing Mix; Increasing Ballroom Sales.

\section{INTRODUCTION}

The tourism industry's rapid development has made the tourism sector a leading sector in generating and increasing foreign exchange. According to the WTTC (World Travel and Tourism Council), in 2018, Indonesia was the growth order of the tourism sector 9 in the world, number three in Asia, and number one in Southeast Asia. One of the destinations that Indonesia has is the island of Bali. Bali is known as the Island of a Thousand Temples. This makes Bali the best tourist destination of the 25 best destinations in the world by Trip Advisor in 2018 (Trimurti \& Utama, 2019). 
The tourists who visit Bali not only enjoy the uniqueness of Balinese culture and traditions, the life of Balinese people, and enjoy the natural beauty that Bali has. Tourists visiting Bali also aim to participate in and organize MICE (Meeting, Incentive, Convention \& Exhibition). MICE is a tourism activity whose activities are a combination of leisure and business, usually involving a group of people together (Kesrul, 2004), a series of activities in the form of meetings, incentive travels, conventions, congresses, conferences, and exhibitions (Simanjuntak, 2013). In the last three years, Bali has often been used as a venue for MICE on a national and international scale, so many hotels from two to five stars provide MICE facilities, giving rise to price competition along with hotel facilities. The international scale MICE activities held in Bali include the Annual Meeting of the International Monetary Fund-World Bank Group (AM IMF- WBG), Our Ocean Conference, World Conference on Creative Economy, Nusa Dua Fiesta, Miss World, Asia Africa Conference, Indonesia Africa Forum, Asia Social Innovation Conference and Asia Pacific Economy Cooperation (APEC).

Seeing these advantages, many hotels provide meeting facilities to take advantage of MICE, which is a trend in Bali. Therefore, hotels that are involved in competition must implement ways and strategies to win the competition. Murti \& Soeprihanto (2010:274) explained, "Marketing Mix is a combination of variables or activities that are the core of the marketing system, namely product, price, promotion, and distribution. In other words, the marketing mix is a collection of variables that can be used by companies to influence consumer responses", according to Wagey et al. (2020). They use marketing communications mix strategy to improve room sales at The Ritz Carlton Jakarta Mega Kuningan. They thinks with the marketing communications mix, hotels will be able to have the opportunities to build brand awareness, brand image, and even creating a unique competitive advantage. The right marketing communication effort is needed to maximize the promotion result. Marketing communications mix concept always continues to develop because it has a strong connection to communication channels, which nowadays keep evolving towards modern digital technology. They use the SWOT analysis to analyze the communication strategy. According to Kotler \& Kevin (2012), firms should choose the correct marketing communications strategies because it is very important to reach the company's customers and strongly relate to the marketing budget to spend on every marketing communication element. If the hotel could formulate and implement the right marketing communications strategies, it could increase brand awareness, market share, develop purchase decisions, and solve the hotel's problem with room revenue.

One hotel that uses a marketing mix in Bali is the New Kuta Hotel. New Kuta Hotel is a four-star hotel with 258 rooms consisting of various types and facilities that support guests' comfort during their stay. One of the facilities that support MICE activities is a Ballroom. According to Hawari \& Dinastry (2016), a hotel ballroom is a large space which is one of the facilities provided by a hotel due to its luxurious design and function. New Kuta Hotel has seven meeting rooms that can accommodate various activities from small to large scale. New Kuta Hotel offers four main meeting packages, namely half day, full day, full board and residential. Room sales data, ballroom, and ballroom revenue at Hotel New Kuta in the last three years are as follows. 


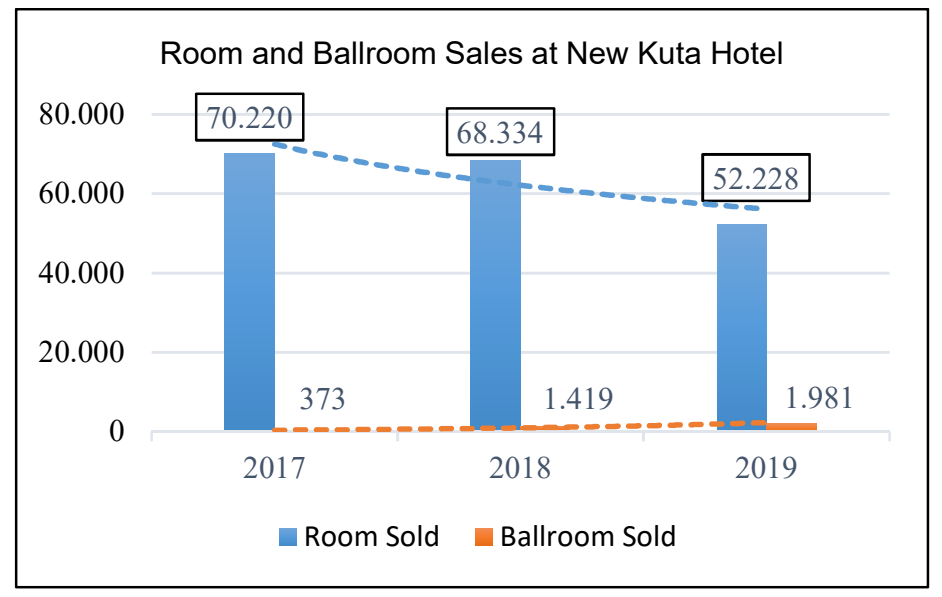

Source: Sales \& Marketing Department of New Kuta Hotel, 2019

Figure 1. Room and Ballroom Sales at New Kuta Hotel in 2017 - 2019

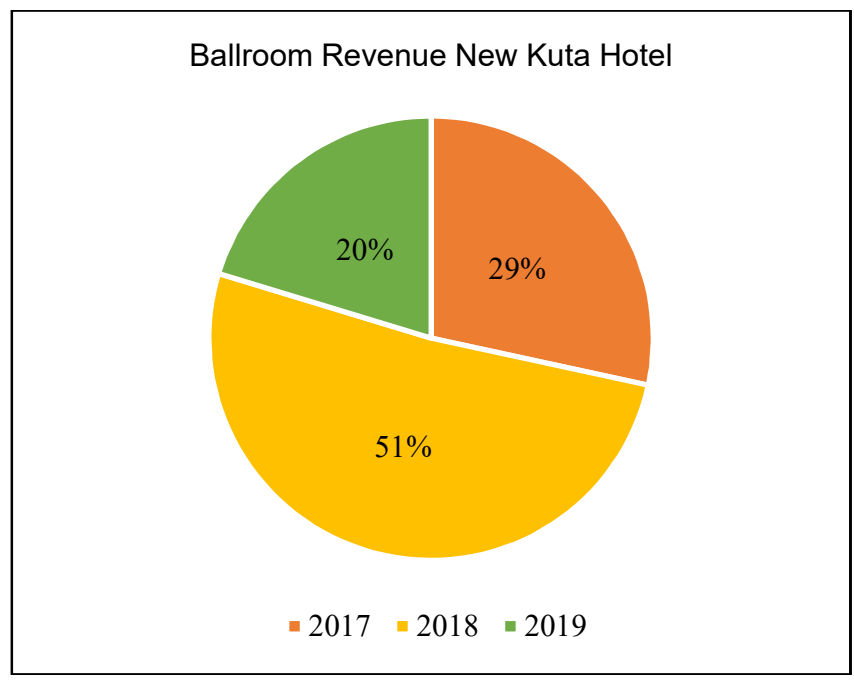

Source: Sales \& Marketing Department of New Kuta Hotel, 2019

Figure 2. Ballroom Revenue in New Kuta in 2017 - 2019

Figure 1 shows that Ballroom sales at New Kuta Hotel in the last three years have significantly increased, moreover Figure 2 shows that revenue from Ballroom sales has decreased. So that it is asynchronous; therefore, this research will analyze the marketing strategies in increasing ballroom sales at New Kuta Hotels. In this study, the method used was FGD (focus group discussion). Where each question from the FGD results will be analyzed using SWOT analysis, this analysis is very different from the analysis used by Permadi et al. (2016). They wrote about the analysis of banquet revenue forecasts after the renovation of the grand ballroom. They used simple regression analysis and T hypothesis test. From the results of this analysis, Sangari et al. provides several strategies to achieve the banquet revenue target, namely the grand ballroom in-progress tour, the live hot open kitchen package and provides several other strategies including digital marketingendorsement, namely efforts to manage hotel management to maximize the use of social media such as Twitter, Instagram, and Facebook as a means of promoting the 
new Grand Ballroom. From the strategy provided by Sangari, the author will use digital marketing to increase ballroom revenue.

\section{METHODOLOGY}

This research is qualitative research; therefore the variables in this research identify internal variables which is the internal factor of the company by using the indicators of promotion mix by Kotler \& Kevin (2012) that consists of product, price, place, promotion, people, physical evidence, and process. External variables consist of the competitive environment, economic environment, natural environment, technology, politics, legislation and regulation and social-cultural environment, budget and sales staff. There are two types of data: qualitative and quantitative, while the sources of data used are primary and secondary data. The method of data collection in this research is a focus group discussion.

FGD is a qualitative research method and data collection technique in which a selected group of people discusses a given topic or issue in-depth, facilitated by a professional, external moderator. In this study, the researcher conducted an interview with all of sales and marketing of the New Kuta Hotel which discussed what marketing strategies could be used in increasing ballroom sales. The sampling method used in this study is saturated sampling. Saturated sampling is a sampling technique when all members of the population are relatively small, less than 30 people (Sugiyono, 2015). In this research, the sampling was all four employees of the Sales \& Marketing Department at the New Kuta Hotel. The purpose of using this FGD, involving four employees of Sales and Marketing, is to be able to develop and create more innovative strategies. Another reason for using FGD method is because a situation like this, namely the Covid-19 pandemic, has slightly hampered this research. This is also one of the weaknesses of this study.

The data analysis technique used in this research was a combination of qualitative and quantitative descriptive. IFAS analysis (Summary of Internal Factor Analysis), EFAS (Summary of External Factor Analysis), SWOT analysis (Strengths Weaknesses Opportunities Threats). SWOT analysis, according to Rangkuti (2016:19), a SWOT analysis is a systematic description of various factors to formulate a company strategy and QSPM (Quantitative Strategic Planning Matrix) analysis. QSPM analysis is used to see what strategy is best to be selected or applied in a company. The flow of data analysis in this research is started by observing and interviewing the internal and external factors of New Kuta HotelPecatu to the four respondents. The second is data sorting and identification of the results into the tabulation of internal and external factors. Each indicator's results in internal and external factors will be used in the questionnaire to be filled up by the respondents to measure the weight, rating, and score of IFAS and EFAS. The total score of IFAS and EFAS will be used to find out the current position of the company by IE (Internal-External) matrix. This IE matrix can be found in what cell and what category the company stands for. The strategy is formulated based on this position and combining the internal and external factors in the SWOT matrix to find out the four types of strategies are SO (Strengths Opportunities) strategy, ST (Strengths Threats) strategy, WO (Weaknesses Opportunities) strategy and WT (Weaknesses Threats) strategy. These strategies are used to make the QSPM questionnaire to find out the total attractive score. This analysis is used to know which alternative 
strategy is the best to be chosen. QSPM matrix uses the data from IFAS, EFAS, and SWOT analysis to determine the relativeness of varieties.

\section{RESULTS AND DISCUSSION}

\section{A. Internal and External Analysis}

The qualitative analysis is started by doing the focus group discussion regarding internal and external factors of New Kuta Hotel to four talents as the key informants. Then, the results of the focus group discussion will be used as a tool in measuring the weight, rating, and score in focus group discussion as the quantitative analysis.

The results of focus group discussion in this research are inputted in the form of IFAS or Internal Factor Analysis Summary matrix (Table 1) and EFAS or External Factor Analysis Summary matrix (Table 2) with the common issue. In this opportunity, the talents of the sales and marketing department, especially the manager, decided the weighting and rating that is shown in both matrix and the results will be used to analyze the position of New Kuta Hotel in the IE or InternalExternal matrix (Figure 1).

The IFAS score is acquired from the weighting of internal indicators that is multiplied by the average rating in each internal indicator. The internal factors in IFAS matrix divided into two categories are strengths and weaknesses. The details of IFAS matrix with total score of 2.88 can be seen in Table 1.

Table 1. IFAS of Marketing Strategic

\begin{tabular}{|c|c|c|c|c|}
\hline No & Strength & Weight & Rating & Score \\
\hline 1 & $\begin{array}{l}\text { It has completed and adequate ballroom } \\
\text { facilities in accordance with } 4 \text {-star hotel } \\
\text { standards as well as various types of rooms } \\
\text { and ballroom layouts. Because New Kuta } \\
\text { Hotel has a ballroom facing the beach, } \\
\text { where tourists can enjoy the sunset. This is } \\
\text { very popular with tourists from China } \\
\text { because tourists from China really like the } \\
\text { beach. This is also supported by the } \\
\text { number of Chinese guests staying at the } \\
\text { New Kuta Hotel around 2,000 Chinese } \\
\text { guests per month. }\end{array}$ & 0.09 & 3.50 & 0.315 \\
\hline 2 & $\begin{array}{l}\text { The strategic location of the hotel is } \\
\text { located at Pecatu Indah Resort area. } \\
\text { The Pecatu Graha area is a very } \\
\text { strategic area, where the area is close to } \\
\text { the centre of tourist destinations such } \\
\text { as Uluwatu Temple, GWK Statue, and } \\
\text { several famous beaches such as Melasti } \\
\text { Beach, Pandawa Beach and Dreamland } \\
\text { Beach which are only } 2 \text { minutes from }\end{array}$ & 0.07 & 3.00 & 0.210 \\
\hline
\end{tabular}




\begin{tabular}{lllll}
\hline New Kuta Hotel. & & & \\
\hline Work according to operational & & & \\
standards & & & & \\
hotel procedure. Where every employee at & & & \\
New Kuta Hotel works in accordance with & & & \\
the standards set by the Management of & 0.09 & 3.50 & \\
New Kuta Hotel, for example, sales and & & & \\
marketing department employees who are \\
required to always look attractive and neat \\
so that they are easy to attract customers.
\end{tabular}

\begin{tabular}{|c|c|c|c|c|}
\hline 4 & $\begin{array}{l}\text { Expectations consist of benefits } \\
\text { obtained } \\
\text { customers when using Ballroom in } \\
\text { accordance with reality. What the customer } \\
\text { imagines is in accordance with what is } \\
\text { obtained. For example, the hotel promises } \\
\text { a ballroom that can accommodate } 600 \\
\text { guests and indeed what customers expect } \\
\text { can be realized by the sales and marketing } \\
\text { of New Kuta Hotel. }\end{array}$ & 0.09 & 3.25 & 0.292 \\
\hline 5 & $\begin{array}{l}\text { Ballroom sales can help increase hotel } \\
\text { revenue. This can be proven by the number } \\
\text { of incentives received by each employee. }\end{array}$ & 0.09 & 3.75 & 0.337 \\
\hline 6 & $\begin{array}{l}\text { Sales \& marketing employee motivation to } \\
\text { sell Ballroom. The thing that motivates } \\
\text { sales and marketing employees to sell and } \\
\text { promote the New Kuta Hotel Ballroom is } \\
\text { to increase revenue from the New Kuta } \\
\text { Hotel which is very influential with their } \\
\text { incentives. }\end{array}$ & 0.08 & 3.00 & 0.240 \\
\hline
\end{tabular}

A good cooperative relationship between sales \& marketing employees. This can be proven by working

7 together between sales and marketing employees of New Kuta Hotel in determining packages for the use of the Ballroom and promotions that will be carried out to increase sales.

$\begin{array}{lll}\text { Total } & 0.60 & 2.024\end{array}$

\section{Weaknesses}

The lack of sales \& marketing employees. Usually, sales and marketing employees owned by 4-star hotels have more than four sales and marketing employees. 


\begin{tabular}{|c|c|c|c|c|}
\hline 2 & $\begin{array}{l}\text { The ability of employees in foreign } \\
\text { languages. Lack of mastery of foreign } \\
\text { languages other than English which is } \\
\text { owned by New Kuta Hotel employees. By } \\
\text { having language skills other than English, } \\
\text { able to expand the target market of the New } \\
\text { Kuta Hotel }\end{array}$ & 0.07 & 2.25 & 0.157 \\
\hline 3 & $\begin{array}{l}\text { The ability of sales \& marketing employees } \\
\text { in conducting promotions and ballroom } \\
\text { sales. Lack of sales and marketing skills in } \\
\text { promoting the Ballroom at New Kuta Hotel } \\
\text { using social media such as Facebook, } \\
\text { Instagram and websites. Whereas by } \\
\text { promoting the ballroom using social media } \\
\text { it will be easier to attract customers. } \\
\text { Because in this era all people more } \\
\text { interested using social media to finding } \\
\text { information in the tourism sector. }\end{array}$ & 0.08 & 2.25 & 0.180 \\
\hline 4 & $\begin{array}{l}\text { Get appropriate incentives if successfully } \\
\text { selling Ballroom. The small number of } \\
\text { incentives that the sales and marketing } \\
\text { department employees get when they are } \\
\text { able to sell the ballroom, where the } \\
\text { incentives received are not up to the } \\
\text { standards of a } 4 \text { star hotel. }\end{array}$ & 0.08 & 2.00 & 0.160 \\
\hline 5 & $\begin{array}{l}\text { The special price of using Ballroom is in } \\
\text { accordance with Ballroom's capacity by } \\
\text { customers who are given sales \& marketing } \\
\text { when offering and promoting Ballroom. By } \\
\text { providing prices according to customer } \\
\text { desires, if } 600 \text { people require a budget of } \\
15 \text { million, it is too expensive for } \\
\text { customers, then it will be discussed to } \\
\text { reduce the package in order to reduce the } \\
\text { cost of using the ballroom. }\end{array}$ & 0.09 & 2.25 & 0.202 \\
\hline & Total & 0.39 & & 0.856 \\
\hline \multicolumn{2}{|c|}{$\begin{array}{l}\text { Total of Weight \& Score to obtain Internal } \\
\text { Factor }\end{array}$} & 1.00 & & 2.88 \\
\hline
\end{tabular}

After analyzing the current situation's internal factors, it is continued by analyzing the external factors faced by New Kuta Hotel that divided into opportunities and threats, which can be seen in the EFAS matrix. The total score in the EFAS matrix is acquired from the weighting of external factors is multiplied by the average rating in each external factor. The details of the EFAS matrix with a total score of 3.12 can be seen in Table 2. 
Table 2. EFAS of Marketing Strategic

\begin{tabular}{llccc}
\hline No & \multicolumn{1}{c}{ Opportunities } & Weight & Rating & Score \\
\hline $1 \quad \begin{array}{l}\text { Hotel Security Enabling environment. The hotel } \\
\text { location is in the Pecatu Graha area which has a } \\
\text { standard security system }\end{array}$ & 0.20 & 3.50 & 0.700 \\
\hline $\begin{array}{l}\text { Rapid technological progress. The } \\
\text { technology used in the New Kuta Hotel }\end{array}$ & 0.15 & 3.50 & 0.700 \\
$\begin{array}{l}\text { Ballroom, such as sound systems and } \\
\text { projectors, is in accordance with the } \\
\text { standards and technological advances in } 4 \\
\text { star hotels. }\end{array}$ & & & \\
\hline $\begin{array}{l}\text { Local cultural appeal. New Kuta Hotel is } \\
\text { located in a tourist area with a local culture } \\
\text { that attracts tourists such as the Kecak } \\
\text { dance at Uluwatu Temple. }\end{array}$ & 0.13 & 3.00 & 0.390 \\
\hline $\begin{array}{l}\text { The ability of sales \& marketing staff to carry } \\
\text { out promotions in bringing/attracting } \\
\text { customers. Sales marketing skills in utilizing } \\
\text { social media to promote ballrooms that can } \\
\text { attract new customers. }\end{array}$ & 0.20 & 3.75 & 0.750 \\
\hline \multicolumn{1}{c}{ TOTAL } & & \\
\hline
\end{tabular}

After analysing internal and external factors, it is continued by moving the score into the Internal-External matrix. In the previous calculation, it was found that the score of IFAS is 2.88 and the score of EFAS is 3.12. These score scans are used to analyze the New Kuta Hotel's position, shown in Figure 1. 


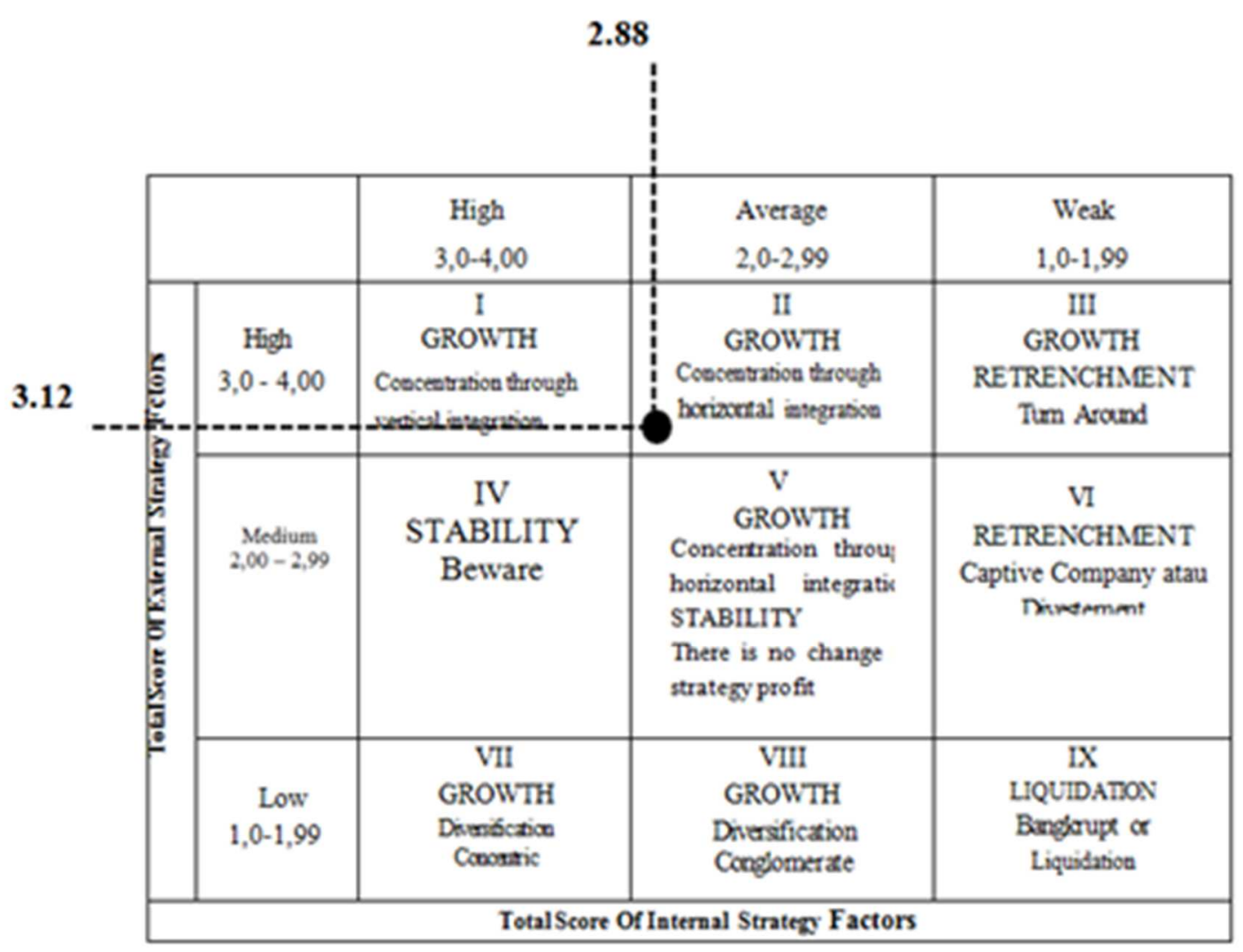

Figure 1. Current Position of New Kuta Hotel by IE Matrix

Figure 1 shows the position of the New Kuta Hotel marketing strategy is in cell II and cell I in the internal-external matrix. Cell II and cell I show that the sales \& marketing department's marketing strategy is at the Growth Strategy stage with concentration through horizontal and vertical integration, both internally by increasing the ability of sales \& marketing employees to do ballroom sales promotions such as making packages at prices special. Externally by utilizing technological advancements to promote products owned and have competitive prices with other hotels. The IE matrix results will be used as consideration in formulating technical marketing strategic alternatives in the SWOT matrix analysis.

Table 3. SWOT Matrix

IFAS/EFAS Strengths (S) Weaknesses (W)

\begin{tabular}{cll}
\hline & SO Strategy & WO Strategy \\
& SO1 - The addition of product WO 1-Increase the number \\
variants in the ballroom such as of sales \& marketing \\
Opportunities & increasing packages for department employees so \\
(O) & ballroom use, bearing in mind that the company's \\
& that New Kuta Hotel has many operations run smoothly and \\
& facilities to develop new can increase ballroom sales \\
products that can support at the New Kuta Hotel \\
ballroom sales.
\end{tabular}


$\mathrm{SO} 2$ - Increase incentive volume when successfully selling ballroom so that sales \& marketing employees are more enthusiastic and motivated when promoting and selling ballroom
WO2 - More optimize hotel product promotions, especially ballroom products for sales \& marketing employees to make it easier to make ballroom sales

\begin{tabular}{|c|c|c|}
\hline \multirow{3}{*}{ Threats (T) } & ST Strategy & WT Strategy \\
\hline & $\begin{array}{l}\text { ST } 1 \text { - Has a dynamic price to } \\
\text { anticipate competition }\end{array}$ & $\begin{array}{l}\text { WT } 1 \text { - Conduct language } \\
\text { training for sales \& } \\
\text { marketing department } \\
\text { employees to make it easier } \\
\text { to do ballroom sales } \\
\text { promotions. }\end{array}$ \\
\hline & $\begin{array}{l}\text { ST2 - Improving the quality of } \\
\text { service to customers, especially } \\
\text { services in the process of selling } \\
\text { ballroom, as well as hone the } \\
\text { ability to do personal selling by } \\
\text { providing training to sales \& } \\
\text { marketing department } \\
\text { employees. }\end{array}$ & $\begin{array}{l}\text { WT2 - Prioritizing guest } \\
\text { satisfaction during the low } \\
\text { season by providing } \\
\text { additional benefits when } \\
\text { using a ballroom, such as } \\
\text { free one night stay at New } \\
\text { Kuta Hotel. }\end{array}$ \\
\hline
\end{tabular}

Based on table 3 above, it can be explained the strategies with details as below.

1. Strategy Strength - Opportunities (SO)

SO (Strengths Opportunities) Strategy Based on New Kuta Hotel's strengths and opportunities, there are two alternative strategies that are recommended in this SO strategy. First is New Kuta Hotel - should create more packages considering that New Kuta Hotel has many facilities to develop new products that can support ballroom sales. And the second is to increase incentive volume when successfully selling ballroom so that sales \& marketing employees are more enthusiastic and motivated when promoting and selling ballrooms, which leads to increased ballroom sales and can optimize profits to be achieved by management.

2. ST (Strengths Threats) Strategy

ST strategy uses the strength to tackle the threats that faced by New Kuta Hotel. The alternative strategy in this ST strategy is New Kuta Hotel. New Kuta Hotel can further promote ballroom sales by offering a reasonably low price that has been considered and adjusted to the desired profit. And improving the quality of service for customers, especially services in the process of selling ballroom, as well as honing the ability to do personal selling by providing training to sales \& marketing department employees. This strategy is expected to attract more customers to come and use ballroom facilities

3. WO (Weaknesses Opportunities) Strategy 
There are two alternative WO strategies that can be used by the New Kuta Hotel to minimize weaknesses and take advantage of opportunities at the same time. New Kuta Hotel can increase the number of sales \& marketing department employees so that the company's operations run smoothly and can increase ballroom sales and further optimize product promotions for employees sales \& marketing department through social media such as Instagram, Facebook and the website.

4. WT (Weaknesses Threats) Strategy

In minimizing weaknesses and overcoming threats, there are two alternative WT strategies that can be implemented by New Kuta Hotels such as New Kuta Hotel. Holding language training for sales \& marketing department employees to facilitate ballroom sales promotion. And prioritizing guest satisfaction by providing additional benefits when using a ballroom, such as free one night stay at the New Kuta Hotel. Providing this will add to the customer loyalty that will benefit the company and with a feeling of satisfaction with the customer, the customer will feel comfortable and think of renting a ballroom again at the New Kuta Hotel.

\section{B. QSPM (Quantitative Strategic Planning Matrix) Analysis}

This analysis's final stage determines the assessment of alternative strategies formulated by using the SWOT analysis matrix previously into QSPM analysis. The purpose of this alternative strategy assessment is to find out the most effective digital promotion strategies that can be applied by W Bali-Seminyak by using QSPM (Quantitative Strategic Planning Matrix) analysis. This QSPM assessment uses the average rating and average alternative strategy that produces the total attractive score (TAS). The calculation formulas are mention as below (Setyorini et al., 2016):

$$
\text { TAS }=\text { Weights } x \text { AS }
$$

Note: TAS (Total Attractive Score)

AS (Attractive Score of alternative strategy)

The output of QSPM is the promotional strategy that formulated for New Kuta Hotel which can be seen in Table 4 as follow.

Table 4. Marketing Strategic

\begin{tabular}{clc}
\hline $\begin{array}{c}\text { Strategy } \\
\text { Code }\end{array}$ & Strategy & TAS \\
\hline & $\begin{array}{l}\text { Increase incentive volume when selling ballrooms so that } \\
\text { sales \& marketing department employees are more } \\
\text { motivated and motivated when conducting ballroom } \\
\text { promotions and sales. }\end{array}$ & 181.29 \\
\hline
\end{tabular}




\begin{tabular}{lll}
\hline WO2 & $\begin{array}{l}\text { More optimize hotel product promotions, especially } \\
\text { ballroom products for sales employees through social } \\
\text { media such as Instagram, Facebook and the website }\end{array}$ & 175.91 \\
\hline SO1 & $\begin{array}{l}\text { Additional product variants in the ballroom such as } \\
\text { wedding packages, meetings, graduations and gala dinners, } \\
\text { considering that New Kuta Hotel has facilities that can } \\
\text { support ballroom sales at the New Kuta Hotel }\end{array}$ & 157.05 \\
\hline WO1 & $\begin{array}{l}\text { Increase the number of sales \& marketing department } \\
\text { employees so that the company's operations run smoothly } \\
\text { and increase ballroom sales at the New Kuta Hotel }\end{array}$ & 148.97 \\
\hline & $\begin{array}{l}\text { Improving the quality of service for tourists and customers } \\
\text { specifically in the service process of selling the ballroom, } \\
\text { as well as honing the ability to do personal selling by } \\
\text { giving training to all sales \& marketing department } \\
\text { employees. }\end{array}$ & 138.66 \\
\hline ST2 & $\begin{array}{l}\text { Conduct a foreign language training program for sales \& } \\
\text { marketing department employees to make it easier to } \\
\text { promote ballroom sales }\end{array}$ & 138.33 \\
\hline WT1 & $\begin{array}{l}\text { Prioritizing guest satisfaction in low season by providing } \\
\text { additional benefits when using the ballroom, such as } \\
\text { providing a free one night stay at the New Kuta Hotel }\end{array}$ & 137.59 \\
\hline ST1 & $\begin{array}{l}\text { Has a dynamic price to face competition } \\
\text { WT2 }\end{array}$ & 132 \\
\hline
\end{tabular}

Table 4 shows the results of QSPM that the management selected for determining the most effective digital promotion strategy that can be implemented by the New Kuta Hotel. The management can apply all the strategies or a few of them. Nevertheless, based on the results of QSPM, the management has scored and chosen three alternative strategies as the priority that can be applied by the New Kuta Hotel for their marketing strategies. The first strategy comes from the $\mathrm{SO} 2$ strategy with a total score of TAS about 181.29 increase incentive volume when selling ballrooms. The second strategy that comes from the WO2 strategy is More optimize hotel product promotions, especially ballroom products for sales employees through social media such as Instagram, Facebook and the website with a total score of TAS about 175.91 and then followed by SO1 strategy which is creating product variants in the ballroom such as weeding packages, meetings, graduations and gala dinners, considering that New Kuta Hotel has facilities that can support ballroom sales at the New Kuta Hotel with total of TAS about 157.05.

\section{CONCLUSION}

Based on the results and discussion of the marketing strategy consisting of New Kuta Hotel's internal and external factors in the previous chapter, the conclusion can be explained as follows. The internal factors of New Kuta Hotel consist of strengths and weaknesses. Their strengths are the products owned by New Kuta Hotel, namely ballroom and packages offered, relatively low prices, online 
and offline distribution channels controlled by the sales \& marketing department and how to do promotions by the sales \& marketing department while their weaknesses are the lack of sales \& marketing department employees at the New Kuta Hotel and the lack of motivation possessed by the sales \& marketing department employees due to the relatively small incentives provided when sales \& marketing employees are able to sell the New Kuta Hotel ballroom.

External factors New Kuta Hotel consists of opportunities and threats. The opportunity is that political conditions in Indonesia are relatively stable, the level of security in Bali is relatively conducive, extensive internet network, development of electronic devices and modern applications, local cultural appeal, the natural environment around the hotel area is well maintained and the threat is the presence of competitors around the Pecatu area which has a similar product, many similar hotels around Pecatu offer lower prices. An appropriate marketing strategy that can be applied by New Kuta Hotel is to create more product variations such as ballroom usage packages, increase incentives for employees who are able to sell ballrooms to customers and more optimize promotion through social media.

\section{REFERENCES}

Hawari, F., \& Dinastry, R. S. (2016). Redesain Interior Ballroom Multifungsi Edelweissm Untuk Meningkatkan Kualitas Akustik (Studi Kasus: Ballroom Edelweiss Idjen Suites Malang, Jawa Timur). Jurnal Sains Dan Seni ITS, 5(2), 2337-3520.

Kesrul, M. (2004). Meeting Incentive Trip Conference Exhibition. Graha Ilmu.

Kotler, P., \& Kevin, K. (2012). Marketing Management (14th ed.). Pearson Prentice Hall.

Murti, S., \& Soeprihanto, J. (2010). Pengantar Bisnis (Dasar-dasar Ekonomi Perusahaan) (5th ed.). Liberty Yogyakarta.

Permadi, S. Y., Djawa, D., \& Sangari, F. (2016). Analisis Forecast Banquet Revenue Pasca Renovasi Grand Ballroom. Jurnal Hospitaliti Dan Pariwisata, 3(2), 114 - 232.

Rangkuti, F. (2016). Analisis SWOT Teknik Membedah Kasus Bisnis. Gramedia Pustaka Utama.

Setyorini, H., Effendi, M., \& Santoso, I. (2016). Analisis Strategi Pemasaran Menggunakan Matriks SWOT dan QSPM (Studi Kasus: Restoran WS Soekarno Hatta Malang). Industria: Jurnal Teknologi Dan Manajemen Agroindustri, 5(1), 46-53.

Simanjuntak, M. (2013). Opportunity for tourism professional development in Indonesia. Binus Business Review, 4(1), 473-486.

Sugiyono. (2015). Metode penelitian pendidikan: Pendekatan kuantitatif, kualitatif dan $R$ $\& D$. Alfabeta.

Trimurti, C. P., \& Utama, I. G. B. R. (2019). An investigation of tourism motivation and tourist attraction of tourists to bali. $J M K, 21(2), 130-133$.

Wagey, A. B., Pitanatri, P. D. S., \& Sujatha, D. K. (2020). Marketing Communications Mix Strategy to Improve Room Sales at The Ritz Carlton Jakarta Mega Kuningan. (TRJ) Tourism Research Journal, 4(1), 45-61. 